\title{
Amazonian Dark Earths in the context of pre-Columbian settlements
}

\author{
Beata Golińska \\ Jagiellonian University, Institute of Archaeology; ul. Gołębia 11, 31-007 Krakow, Poland; e-mail: bea.golinska@gmail.com \\ (C) 2014 Authors. This is an open access publication, which can be used, distributed and reproduced in any medium according \\ to the Creative Commons CC-BY 4.0 License requiring that the original work has been properly cited.
}

Received: 4 September 2013; accepted: 14 June 2014

\begin{abstract}
Important information about pre-Columbian Amazonian settlement and economy provide Amazonian Dark Earths (ADE), black or brown soils characterized by the presence of charcoal in high concentrations, with highly elevated nutrients and organic matter and higher $\mathrm{pH}$ level. Usually ADE are related to large concentrations of ceramics, stone artifacts and animal remains. The main factor for the initiation of ADE formation was the long-lasted, fully sedentary pre-Columbian settlement. Its size and a form can be correlated with traces of historical human habitation. Thus, these sites can reflect the social organization of a specific group. Therefore, ADE studies can bring much valuable information concerning pre-Columbian settlement in Amazonia.
\end{abstract}

Keywords: Amazon, anthropogenic soils, pre-Columbian settlement, Amazonian Dark Earths, terra preta

\section{INTRODUCTION}

Studies on the environment and its modifications by the former communities of tropical forest areas play a unique role in understanding of Amazonian prehistory. The most evident argument for the presence of large groups of people in the Amazonia are "black earths" (Amazonian Dark Earths - ADE), especially their variation - terra preta. ADE are considered as a result of past Indian actions, who more or less consciously enriched the soil with charcoal, organic waste and ceramics shards. Therefore, ADE are proof of the existence of large and numerous prehistoric settlements in Amazonia as well as the artifacts themselves.

\section{Study area - environment and soils of Amazonia}

Moist tropical forests, extremely rich and varied, hide poor and barren ground. Amazonian soils, exposed to continuous heavy rainfall, are examples of intensive leaching processes. As a result, they are weathered and acidic and almost completely devoid of essential nutrients (Mann 2007: 373).

Almost the entire area of Amazonia is covered by an acidic and infertile laterite soil: red soils (ultisols, color result from the accumulation of iron) and yellow laterite soils (characterized by the presence of a high concentration of hydrogen ions and a high acidity). A large number of iron compounds and the acidity make laterite soils conditions practically not suitable for efficient cultivation. The major divisions of tropical soils include also ferralsols (ferralitic soils) characterized with a low natural fertility. The exceptions are for example fluvisols (fluvial soils), mineral-rich alluvial deposits located in the Amazon River Basin.

In 1989, the Polish Society of Soil Science has proposed a system of soil classification with major divisions into seven hierarchic soil units including: I) lithogenic, II) autogenic, III) semi-hydrogenic, IV) hydrogenic, V) alluvial soil, VI) saline and VII) anthropogenic. For the purposes of this article it will discuss only the section VII 
including soils transformed as result of past human activities, including burial, partial removal, cutting and filling, waste disposal and irrigated agriculture (anthrosols).

Anthropogenic soils, formed under the influence of human activities are typologically transformed. Different profile horizons, the lack of some genetic levels or the presence of new, bio-physico-chemical and hydrological transformations as a result of municipal agriculture and industry lead to the division of two orders: culture earth soils, transformed under the influence of intensive management and industrial earths and urban soils. Anthrosols, are formed as a result of direct (irrigation, addition of organic waste or wet-field cultivation) or indirect (through the modification of vegetation, deforestation) human activities. Such processes can be intentional or random. Deliberate actions aimed at improving the quality of the soil are likely to occur simultaneously with the spread of agriculture (Woods 2003). Fertilizers were used during the reign of the pharaohs in Egypt. Hesiod and Xenophon mentioned that Greeks were fertilizing their fields to improve their fertility. In Carthage, bird droppings were used as a fertilizer. Also Cato and Columella, the Roman authors recommended pigeon droppings as an ideal fertilizer. Guano was also highly appreciated by the Incas.

In Amazonia, among the best-known examples of anthrosols are Amazonian Dark Earths (ADE), very dark in color, with a great amount of broken pot sherds, highly elevated levels of $\mathrm{pH}$ and increased concentrations of organic matter. These characteristics make them extremely fertile. ADE encompasses two specific types, a classic form: terra preta - "black earth" (also known as a terra preta do indio - „Indian black earths”; terra preta antropogenica - "anthropogenic black earth" or terra preta arqueologica - "archaeological black earth"; Petersen et al. 2001: 86, Sombroek et al. 2002: 2, Kämpf et al. 2003: 78, Lehmann et al. 2003: 105, Woods et al. 2004: 3, Maris 2006: 624) and terra mulata ("brown earth"; Fraser et al. 2009: 229, Kern et al. 2003: 71, Myers et al. 2003: 18, Woods et al. 2009: 1). Both of these soils are characterized by a high content of charcoal, which gives them the typical dark brown or black color. Scholars calculated that ADE contains 64 times more charcoal than other surrounding soils (Glaser et al. 2004, Thayne et al. 2009: 279).

\section{AMAZONIAN DARK EARTHS - Terra preta}

Amazonian Dark Earths are ubiquitous at archaeological sites in Amazonia and cover 6-18 $000 \mathrm{~km}^{2}$ of forested areas of lowland Amazonia (Woods et al. 2009: 1). Most of the sites are located in terras firmes (uplands, forested area above the seasonal inundations), on the headlands, on the banks of watercourses or lakes, or on várzea ("flooded forest"), annually flooded plains (Kämpf et al. 2003: 78, Kern et al. 2004: 19).

Early scholars and explorers reported densely populated villages extending along the river running sometimes for several kilometers and a thick network of roads connecting big settlement clusters located more inland. Research indicates that terra preta can reflect the location of those settlements (Woods et al. 2004: 3). Thus, came the idea of the anthropogenic nature of these soils. Specification of terras pretas, high concentration of charcoal and the frequent occurrence of pottery fragments and stone artifacts seem to confirm this hypothesis.

In comparison to the otherwise infertile Amazonian soils ADE are highly fertile (Glaser et al. 2004: 9) and can be found practically on all of its territory. The problem with its origins and the role that they have played in the cultural processes in the pre-Columbian period for years have been discussed by a broad group of archaeologists, anthropologists, geographers, and soil scientists. Many theories considered the process of formation of those extremely fertile soils have been proposed, from purely random natural processes to intentional activities including soil fertilization. Most researchers agree with the view that terra preta is anthropogenic in nature, although it is not clear if it was formed intentionally or unintentionally (Neves et al. 2003: 29). Either way, it was created as a result of past human activities.

One of the most essential problems in $\mathrm{ADE}$ studies is a different approach to these soils and different ways of their research. The lack of one valid definition or even a clear indication of its characteristics poses many problems. Researchers, who map and identify ADE typically rely on the classification of the lands used in archeology and their interpretations; which, unfortunately, are rarely consistent with contemporary knowledge 
of soil science. However, the archaeologists are experts in understanding and interpretation anthropogenic soils, associated with human activities occurring at sites in Amazonia. Soil scientists, on the other hand, focus on the horizons seen in the soil profiles, considering anthropogenic characteristics as perturbations and interferences. In contrast, archaeologists focus on the visible and structural features in the profiles of anthropogenic formation, perceiving soil levels as perturbations and disruptions. They focus mainly on the internal features of ADE: changes in texture, color, context, and filling. Traditional archaeology focuses on building chronology, by describing profiles of small, but often deep ADE excavations (Erickson 2003: 462).

\section{The history of ADE studies}

Knowledge of the historical Amazonian communities and their farming methods is mainly based on historical records: early conquistadors, chroniclers and travelers' relations. Unfortunately, most of these reports focus on the description of the Indians themselves, devoting little space to issues of the economy and the environment in which they lived (Myers et al. 2003: 21-22).

For the first time ADE was identified in the nineteenth century (Erickson 2003: 456). During this period, records of this phenomenon were limited to short notes. In many cases, terra preta was not even mentioned (Woods et al. 2009: 3).

Nineteenth-century ADE scientists, geologist Charles Hartt, his assistant Herbert H. Smith and later Friedrich Katzer working in the Amazonia, describe in detail the nature of these soils (Petersen et al. 2001: 88, Woods 2003: 3). All of them were aware of the vast area of ADE and suspectedly its anthropogenic origins. Smith wrote: "everywhere we find the scattered pieces of Amerindian pottery shards [...] land on the edges of bluffs owe their richness to remnants of the thousands of kitchen middens accumulating for thousands of years [...]" (Smith 1879 quoted after Woods 2003: 3, Woods et al. 2009: 4). Herbert H. Smith in his book Brazil: The Amazons and the Coast (1979) and in an article An American Home on the Amazons (1879) attributed ADE to the former settlement of Amazonian indigenous people. Hartt introduces a term "kitchen middens" to identify areas in the vicinity of the settlement where all post-production waste was accumulated (Woods et al. 2009:4).

Friedrich Katzer, author of pioneering works on ADE, in his work on the geology of the Amazonia (1903) stated that the "most characteristic richness (of Amazonia) lies in the soil" (Woods et al. 2009: 8). Based on the results of three years of field research (1895-1898) he estimated that the area between the drainages of Tapajós and Curuá Una is covered by "Schwarze Erde" (Woods et al. 2009: 8), which have completely different origins than chernozems from Central Europe (Woods 2003: 3). He stated those soils consist of a characteristic mixture of mineral deposits, carbonized plant material and partially distributed organic substances. Moreover, the estimated content of organic matter was 15-20\% (Woods 2003: 4). Because of its unique richness, writes Katzer, ADE was used by indigenous communities in the past, when the area was densely populated (Woods 2003: 4). In 1944, excerpts from Katzer's book A Terra Preta (1903) was published in Brazil, being the first publication devoted entirely to terras pretas. Similar observations noted by British geologist, C. Barrington Brown describing the black soil of the New River in Guyana: "[...] in two places, even in the forest, ancient villages were found, marked by deep black earth mixed with pottery shards" (Brown 1876 quoted after Woods et al. 2009:4) and along a bluff near Obidos: "undeniably artificial origin [...] Agricultural land highly prized because of its fertility, known as terras pretas (black earth)" (Brown, 1878 Lidstone quoted after Woods et al. 2009: 4). In this paper, Brown and Lidstone were the first to introduce the term terra preta to the modern literature.

The end of the nineteenth century brings new scientific reports informing about ADE presence in different regions of the Amazonia. Combined with the ubiquitous Indian artifacts, the anthropogenic origins of ADE have been stressed.

Despite the early interest of origins of the terra preta issue, for over half of a century ADE has been left on the margins of contemporary research, leaving many issues unsolved. Up until the 1920s of the twentieth century, we see no major progress in the study of ADE (Woods et al. 2009:5). At that time, the best known ADE sites were situated on the river Tapajós, near the city 
of Santarém. Anthropologist, William Farabee, during his trip in 1915 discovered large area of terra preta sites on the northern edge of the river bluff on Belterra plateau, which interpreted as a trace of past settlement in this place. ADE reached 30-60 $\mathrm{cm}$ deep and covered about 4 ha (10 acres) (Petersen et al. 2001: 90, Woods et al. 2009: 5). In 1927, professor and adventurer from Michigan, Joseph Steere, based of his research in the area of Santarém stated that "there is no doubt that these sites are the remnants of ancient cities" (Steere 1927, quoted after Woods et al. 2009: 5). In 1923-1925, Curt Nimuendajú conducted excavations and research of ADE surface on the lower Tapajós. He believed that ADE developed as a remnant of the ancient Indian villages associated with the permanent settlement and fertile soils, formed as a result of those settlement, were used as arable land. In the work from 1925, entitled Die Tapajó he presented the location of many terra preta sites mapped two years earlier (Woods et al. 2009:5).

The 1940s to the 1960s are a period of denial of earlier theories about their anthropogenic origin of ADE. Many observers reported their existence, but instead of analytical studies, they focused on searching for natural causes of their emergence (Glaser et al. 2004: 10, Myers et al. 2003: 23, Woods et al. 2009:7). Brazilian agronomist, Felisberto Camargo believed that terra preta was formed as a result of volcanic dust deposition (1941, Erickson 2003: 459), an archaeologist Barbosa de Faria (1944, Erickson 2003: 459) pedologists Cunha Franco (1962, Erickson 2003: 459) and Italo Falesi (Erickson 2003: 459) argued that terra preta was formed as a result of the accumulation of organic matter in ancient lakes and ponds.

The breakthrough came in 1966, when Danish soil scientist, Wim Sombroek, the "father of Amazonian Dark Earths", published a classification of "Amazon Soils", being the first who noticed differences between terras pretas and other varieties of ADE, formed by waste accumulation at a specific site within the settlement area or brown earth, called terra mulata, which, as he believed, owed its traits from a long-term cultivation (Woods et al. 2009: 8).

Archaeologist Betty Meggers in her bestselling book Amazonia: Man and Culture in Counterfeit Paradise draws attention to the issue of ADE
(Meggers 1971: 132-134), moving this important issue to a wider audience outside of Brazil. However, in this book Meggers diminished the importance of cultural processes in soil formation in the Amazonia. Twenty-five years later, she reviewed her theories by assigning ADE development to brief, repeated periods of residence in the area for hundreds of years. The Brazilian-American geographer, Hilgard Sternberg, who dedicated an entire dissertation to ADE, summarized Meggers theories as that: "puzzling that in an environment such as Amazon, whose potential was estimated to be insufficient to sustain a large concentration of population and sustainable settlement (Meggers 1954), a native settlement could survive for such a long time" (Sternberg, 1975 quoted after Woods et al. 2009: 7).

\section{Properties of ADE}

Terra preta is a product of ancient anthropic activities. The combination of its specific features define soil horizons as an archaeo-anthropedogenic, which is the key to identify this group as archaeo-anthrosols (Kämpf et al. 2003: 88, 89). This horizon is the result of a long, continuous settlement in one area and its characteristic properties developed by additional impurities accumulated over a long period of time, i.e. wastes, organic materials (Kämpf et al. 2003: 90). Terras pretas differ from the surrounding soils of dark color, thickness (at $57 \%$ of documented archaeological sites of ADE layer of humus reaches a depth of 30-60 cm, Kern et al. 2003: 68), the presence of ceramic shards and stone artifacts (Kämpf et al. 2003: 83) and a large amount of charcoal (black carbon or pyrogenic carbon - PYC) and high concentration of organic matter. In terms of chemical features $\mathrm{ADE}$, terra preta in particular, are characterized by a high concentration of carbon and nutrients, such as phosphorus, calcium, magnesium, zinc and manganese (Schaan et al. 2009: 127).

The most important indicator of anthropogenic soils is their color (Woods 2003: 9), a reflection of the cultural remnants of soil saturation, calcium carbonate content and the concentration of iron and magnesium. Earths containing large amounts of calcium carbonate and ash can become white. By slow oxidation of the iron as a result of weathering processes or heat sources they can adopt a red color (Woods 2003: 9). The color 
of the soil is also affected by the presence of ash, charcoal and weathering products. It varies depending on the concentrations of all components, the time of exposure to weather conditions such as temperature and precipitation.

Another most important ADE characteristic is phosphorus. In the 1920s, a Swedish researcher, Olaf Arrhenius, conducted research on the chemical properties of soil (Woods 2003: 6). An interpretation of those results was the first attempt to approach studying prior settlements from a soil science perspective. He argued that human settlement causes chemical changes in the structure in the soil by deposition or decomposition of organic and inorganic wastes. The differences can be used to interpret the history of the area before its settlement and after its abandonment. Therefore, phosphorus, found in most of the cultural residues, is the ideal anthropogenic marker. The element in the form of phosphate $\left(\mathrm{PO}_{4}^{3-}\right)$ occurs at most habitation sites. Urine, plants and animal tissues contain large quantities of P. High concentrations of phosphates in the soil come from three main sources: minerals, whose main representative is apatite, plants (some plants contain a large amount of phosphate) or human remains (high content of phosphate in the soil also is noted in their graves; Woods 2003: 6-8). Human and animal bones are composed of apatite, mainly of hydroxylapatite. These additional substances are readable in the soil structure. Walter Lorch went a step further in developing a method of phosphate testing. Conducting research in Germany and in Eastern Europe he noticed that the differences in the settlement of societies with different economies leaves different marks in the distribution of phosphates (Woods 2003: 6). By comparing those diagrams from various sites he was able to create soil profiles specific for different types of management in human prehistory. For example, while on Stone Age sites phosphate concentrates within a limited area; while in temporary habitation zones they are spread over a much wider area (Woods 2003: 7).

The $\mathrm{pH}$ is employed as probably the most important chemical indicator which can be used (Woods 2003: 9). The $\mathrm{pH}$ was introduced as an archaeological marker for comparing the relative past of some cultural and natural profiles, defining the limits of a site, identifying the stratigraphy of waste middens and other places where ranges were not sufficiently clear, and finally, for identifying sites where the layers are disturbed. The increase in $\mathrm{pH}$, associated with human activity, is attributed primarily to the presence of ash and charcoal. They also contain carbonate and calcium hydroxide, calcium sulfate, sodium, potassium and sodium carbonates and sulfates. The presence of wood ash in the cultural deposits may prevent the growth of acidity, which could be caused by the decomposition of organic residues. As the rainforest environment in general is not conducive to the preservation of organic remains, the ability of carrying out research determining the $\mathrm{pH}$ value of a particular area of human activity plays an important cognitive role.

Other indicators of anthropogenic soils encompass carbonates, carbon, nitrogen, calcium, potassium and magnesium (Woods 2003: 10, Schaan et al. 2009: 127). Carbonates suggest large amounts of wood ash deposited in the soil, their presence may also provide clues about the processes of plant and animal remains decomposition (Woods 2003: 10). Calcium also derives from human and animal excrement, as well as from various organic and inorganic residues (Schaan et al. 2009: 127).

\section{Localization of ADE}

ADE widely distributed in the Brazilian Amazon are found in a variety of different climatic, geological and topographical conditions, are normally surrounded by other much less fertile soils (Fig. 1) (Kämpf et al. 2003: 78). Sombroek estimated that ADE covered $0.1-0.3 \%$ of the Amazon region, which is $6-1800 \mathrm{~km}^{2}$ (Erickson 2003: 463, Sombroek et al. 2003). According to other estimates, the total area of soils partially or completely anthropic covers more than $10 \%$ of the entire Amazonia. This includes areas used for cultivation, uplands related to the aquatic economies and, finally, terras pretas and terras mulatas (Hecht 2003: 356). Due to the relatively small size in comparison to the surrounding soils, ADE occurs on soil maps only as inclusions. Over $80 \%$ of $\mathrm{ADE}$ areas cover less than 2 ha, only a few reach several hundreds of acres (Fig. 2) (500 ha - Santarém, Belterra 200 ha, 80 ha Manacapuru, 90 ha of Altamira) (Erickson 2003: 463, Kern et al. 2003: 68, Woods et al. 2004: 3, Schaan et al. 2009: 128, Woods 2009: 2). 


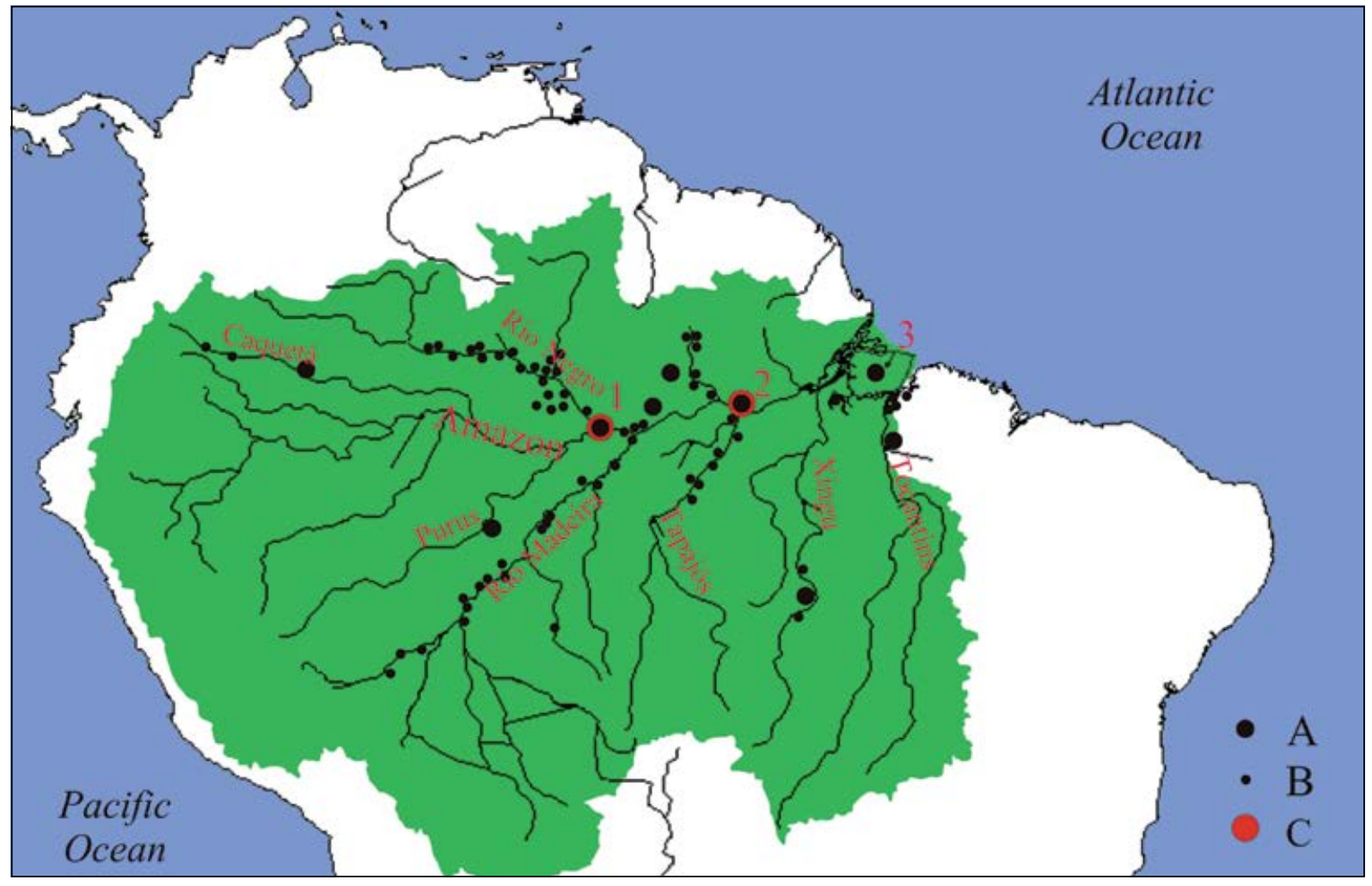

Fig. 1. Selected Amazonian Dark Earths (ADE) sites (after: Kern et al. 2003, Lehmann 2003, Mora 2003, Neves et al. 2003, 2004, German 2004, Rebellato et al. 2009, Schaan et al. 2009, Schmidt 2009): A - cluster of ADE sites, B - single ADE site, C - contemporary cities, 1 - Manaus, 2 - Santarém, 3 - Marajó Island

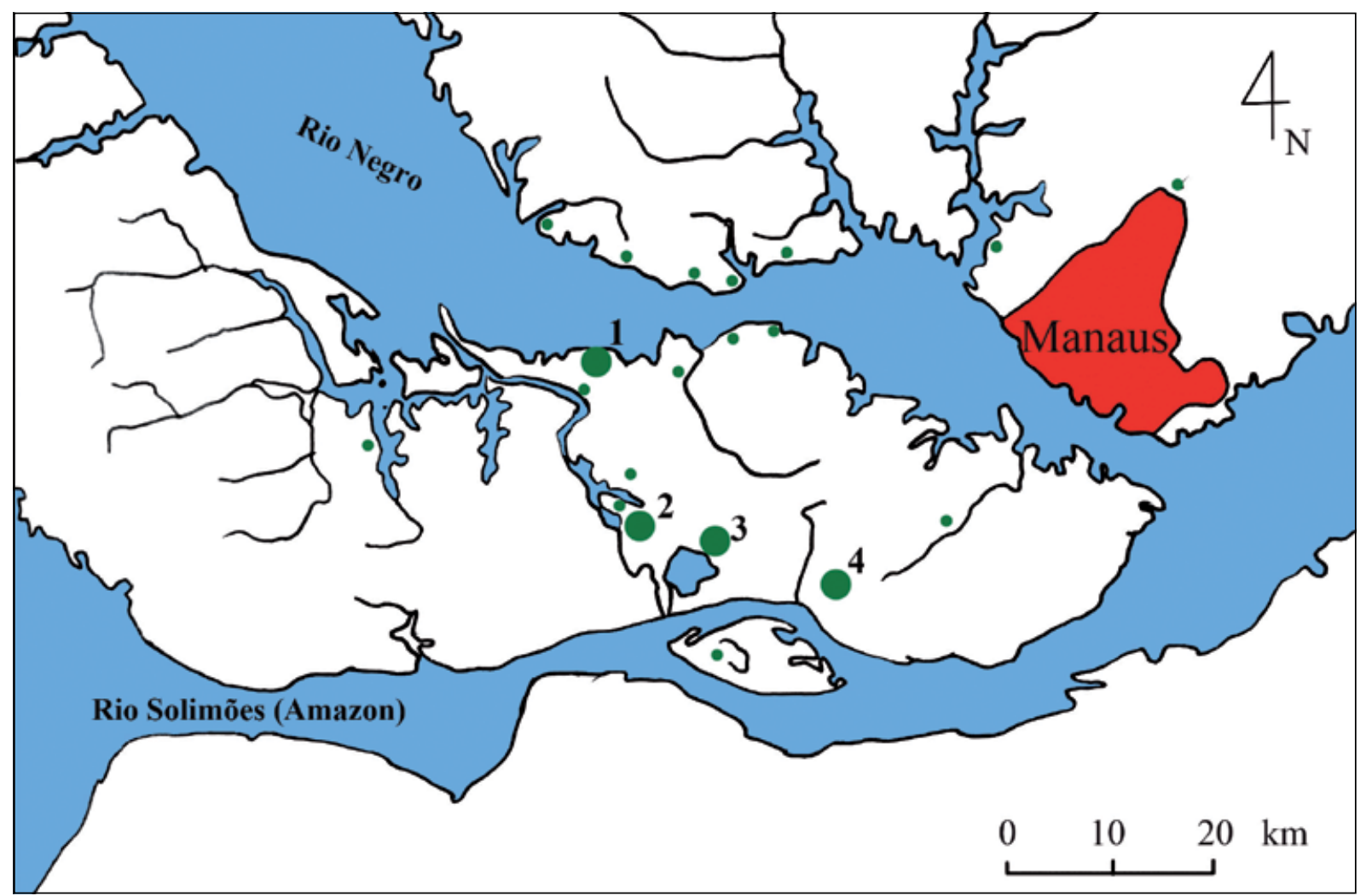

Fig. 2. Location of selected ADE sites in the vicinity of Manaus city (after: Neves et al. 2004, Rebellato et al. 2009). 1 - Açutuba, 2 - Osvaldo, 3 - Lago Grande, 4 - Hatahara; $\bullet$ other archaeological sites 
Usually we find ADE on banks of watercourses, floodplains (várzeas), edges bluff sites and slopes located on the terras firmes (Denevan 1996: 664, Kämpf et al. 2003: 78, Kern et al. 2003:73). In addition to Brazil, ADE is also encountered in Colombia, Peru, Venezuela and Guyanas (Erickson 2003: 463, Kern et al. 2003: 73). They are less common are in the upper Amazon in Peru, Ecuador and Llanos de Mojós in Bolivia. Differences may come from different cultural traditions. Bolivian sites are most likely part of a larger cultural phenomenon associated with oval villages connected with the communities from the upper Xingu, Guapore/Itenez (modern border between Brazil and Bolivia) and the Madeira (Erickson 2003: 465). They can be associated with the phenomenon of ring-ditch sites consisting of trenches and embankments formed in various geometric patterns.

In the years 1985-1986, archaeological projects conducted systematic research along the Xingu and Trombetas rivers. Using information provided by the local communities these projects were able to locate many of archaeological/ADE sites in the study area (Kern et al. 2003: 53). About 45\% of the sites were located 5-25 $\mathrm{m}$ from a water supply. It was also confirmed that the majority of sites are situated on the edges of plateaus, places hard to be reached, far from water sources, which may be associated with worsening military conflict (Kern et al. 2003: 53). Recent geo-pedological studies conducted in the southeastern part of the State of Amazonas (Brazil) and in the northeastern part of the State of Rondonia yielded new information about the deployment of ADE. It is estimated that for one site of this type per every $2 \mathrm{~km}^{2} \mathrm{ADE}$ are located approximately every $5 \mathrm{~km}$ (Kern et al. 2003: 52, Erickson 2003: 463).

\section{Formation of ADE}

Through the years, various theories explaining the formation processes of terra preta have been proposed, from the concept of volcanic deposits (Hilbert 1968 quoted after Glaser et al. 2004: 10) throughout river alluvium (Zimmermann 1958, Franco 1962 quoted after Glaser et al. 2004: 10) to random deposition processes of anthropogenic materials originated from intentional human activities transforming the environment into a more productive one (Glaser et al. 2004: 10). There were even theories that terra preta has been fertile long before their colonization by indigenous communities (Glaser et al. 2004: 10) and that gave impetus to settlement development.

Although we know quite well what the product is terra preta, nevertheless we still have the problem to identify the processes that led to its creation. Scholars are constantly looking for new sources of its formation.

These formation processes presumably comprise three main paths, which can be summed up in three models:

1) midden model - ADE formed during longterm settlement, as a result of unintentional anthropic activities (Erickson 2003: 477, Kämpf et al. 2003:79);

2) agricultural model - intentional agricultural activities based on an intensive slash-and-burn economy (Kämpf et al. 2003:79);

3) moundbuilders model - including all intentional activities based on the building of earthen mounds and raised fields for residence, and burials, and for the latter, agricultural activities.

The midden model might have led to the creation of terra preta; the agricultural model on the other hand to the formation of terra mulata. The moundbuilders model includes archaeological mounds which are not necessarily related to ADE formation. They include large concentrations of residential, ceremonial or defense mounds found on the island of Marajó, mounds found in southern Brazil and similar structures known from Llanos de Mojós (Moxos) in Bolivia, as well as mounds at the juncture of the Negro and Solimões rivers (Kämpf et al. 2003:79).

Woods presented three alternative attempts to explain the occurrence of anthrosols (Woods 2003: 12). The first assumed that ADE are natural sediments and layers that were influenced during their developmental sequence by human activities more or less in the same way as other sites which do not have the characteristics of ADE. The second presented anthrosols as a mixture of natural sediments and debris from the human settlements. The third, the most probable, treated ADE as a cultural artifact formed by deposition and an accumulation of materials created as a result of past human activities. Build-up of layers began when the deposition rate of cultural residues exceeded 
losses by the volatilization of organic compounds, products of leaching or erosion. Index deposition refers to the population size and depends on accumulation or utilization. Unlike in the first and second cases, the third alternative assumed that the process of soil formation is completely dependent on the deposition of anthropogenic materials (Woods 2003:12).

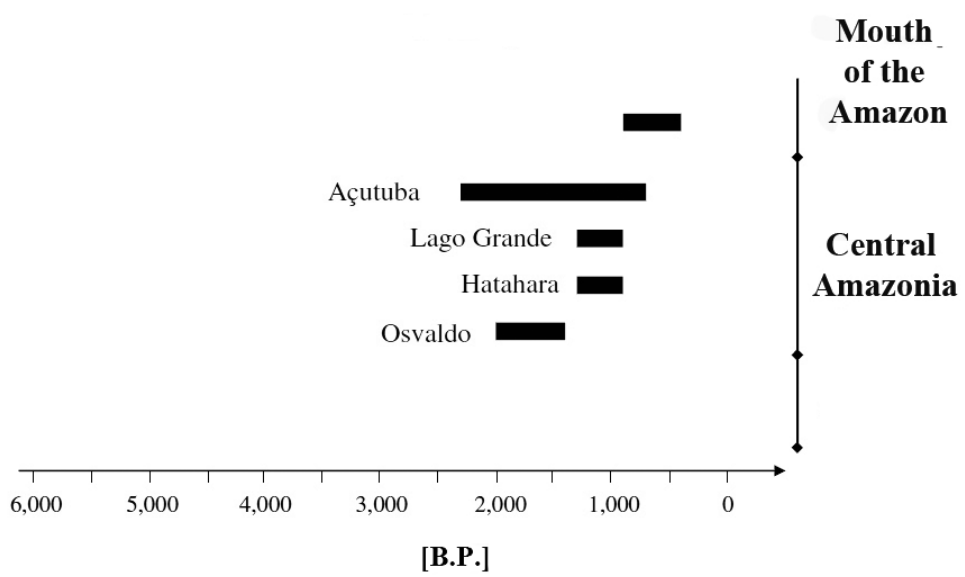

Fig. 3. Chronology of selected Amazonian Dark Earths sites (after Neves et al. 2003)

Most scholars agree that the origins of $\mathrm{ADE}$ are related with a pre-European settlement in the Amazon Basin (Petersen et al. 2001: 88, Neves et al. 2003: 29, Thayn et al. 2009: 279) and terra preta de indio was created by indigenous Amazonian communities hundreds or even thousands of years ago (Petersen et al. 2001: 88, Woods et al. 2009: 1). The formation of these areas must be associated with major social changes which have occurred along the lowland areas of South America in the beginning of the first millennium $\mathrm{AD}$ or even earlier (Fig. 3) (Neves et al. 2003: 30). Although most researchers see the first millennium $\mathrm{AD}$ as the beginning of $\mathrm{ADE}$ formation in the Brazilian Amazon, there are sites dating back to the times before the given period (Petersen et al. 2001). An example can be Paredão, the archaeological site near Manaus, dated to 450 BC (Petersen et al. 2001: $100)$, sites on the Jamari River in Rondonia dated to 2500 BC (Miller 2003, 2006) or Hupaiya, Yarinacocha on the Ucayali River in Peru dated 200 BC (Eden et al. 1984:126). This period is characterized by the presence of oval settlements associated with the emergence and spreading of Arawak-speaking societies. These changes brought transformations in the relationship between society and nature, simultaneously pulling together dramatic and long-lasting transformations of landscape, including terra preta appearance.

However, we can not discuss only one impulse-element of ADE creation. First of all, you can not find a single causative factor of this process, because on does not exist. Environmental conditions vary throughout the range of $\mathrm{ADE}$, the same goes for climate, vegetation, topography, and soil types. This means that the economy, the type of food as well as the survival strategy of the population will be significantly different in different parts of the Amazon at different times. This implies changes in the quality and chemistry of materials that come in contact with the soil. Similarly, a variety of human activities that have led to the formation of ADE or even the organization of a household (e.g. the presence of the higher phosphorus content in one particular place). Similarly, in modern Kuikuru villages in the upper Xingu we can observe two different disposal traditions - middens behind dwellings and a clean plaza in a front. Both of these areas are spaced apart by only one meter and the difference in chemical and physical processes occurring in them is enormous (Neves et al. 2003: 36).

In addition to synchronous and diachronic diversity, temporal heterogeneity is also evident. Regional differences in age of ADE due to the dynamics in social changes and evolutionary development, reflect the changes in human populations throughout history in the Amazon. Capturing the initial stage of this process encounters significant difficulties. The population density obviously changed though time, from a few small communities with a relatively small number of residents per village to the densely populated settlements, larger populations that occurred over time. The depth and nature of ADE at each site can be vary (Neves et al. 2003: 36). With time, the transition from hunting and gathering to agriculture resulted in changes in the quantity and quality of the materials that have been brought to the village and thus 
followed the differences in materials penetrating the soil (Neves et al. 2003: 37). The ADE formation must therefore vary in time and space.

Due to the distinctive landscape transformation processes, the earliest ADE sites disappeared from the archaeological context. Organic material from older posts has mineralized leaving only inorganic artifacts that did not stain soils with a typical dark color making it unreadable (Neves et al. 2003: 38). Any attempt to determine the beginning of the formation process of these soils is therefore difficult. This is another problem concerning this specific region that researchers must struggle with. If it is true that $\mathrm{ADE}$ is an accidental product of human settlement it is also indirect evidence for a dramatic increase of population numbers in the Amazonian communities during this period. Since the first settlers arrived to Amazonia between at least by 11 thousand years ago, processes of ADE formation must thus be correlated with the establishment of a fully sedentary lifestyle based on the development of agriculture in the $3^{\text {rd }}$ millennium B.P. (Petersen et al. 2001, Neves et al. 2003). Plant cultivation as the main means of food production in Amazonia was the key factor for the development of ADE. Intensive agriculture requires continuous improvement of soils, therefore terra preta partially may be the result of those intentional anthropogenic activities. When agriculture developed in Amazonia, specific residential and economic patterns occurred in the area lasting until the appearance of Europeans. In other words, a sedentary lifestyle and the type of economy were the primary prerequisite for the development of ADE (Neves et al. 2003: 39). At present, it is assumed that a sedentary lifestyle occurred in Amazonia, even a thousand years before the advent of ADE (Erickson 2003: 477), so it should not be taken into account as the process of their formation.

In the context of the settlement, possible sources of $\mathrm{ADE}$ may be fragments of clothing, post-consumer waste, pottery, remains of fires, house components and equipment, garbage and excrement (Erickson 2003: 480, Neves et al. 2003: 40, Woods 2003: 3). Most scholars mention activities related with funeral practices as one of the possible reasons for the occurrence of ADE. Today, many indigenous groups bury their dead under the floors of their homes or in the center of the village. Others cremate their dead whose ashes are left in the place of cremation or consumed in the form of a drink during rites. Others, however, leave the house or even the whole village, leaving the deceased in a hammock belonging to the deceased and then set fire to all of the houses (Kern et al. 2004: 22). Of course, one cannot deny that funeral practices had to played a role in this process, but human bones and funeral urn fragments are found very rarely terra preta contexts. Near Manaus, on Rio Solimões, in Hatahara site (Petersen et al. 2001: 41) funerary urns were discovered below ADE horizon (Neves et al. 2003:41). The appearance of ADE in this area, dated around $360 \mathrm{BC}$, is one of the earliest terra preta and terra mulata sites (Petersen et al. 2001: 100). However, the burials themselves were not associated with this horizon in any way. Therefore, we can exclude the contribution of burials in the creation of ADE.

One element, which could play a major role in shaping the course of anthropogenic soils in Amazonia is the process of preparing food and the resulting remnants of it (Neves et al. 2003:41). As I have repeatedly emphasized, ADE owe their color to a large amount of black carbon and incompletely burned organic remains. More than $1 \%$ of ADE consists of carbon (Erickson 2003: 478, Sombroek et al. 2003). This material, similar to charcoal is derived from the cooking fires, earth ovens, and other facilities where a lack of oxygen results in char formation. In order to explain the formation of terra preta by the content of carbonized materials, we must assume that kitchens, dwellings and thus fireplaces changed their locations through time or take into account the existence of very large groups of people. Of course, an area covered by a single fireplace was relatively small but we have to consider the possibility of the dispersal of ash and other combustion byproducts to a much larger area outside the house. This, in turn explains the high concentration of calcium and phosphorus in ADE content. Fish bones, on the other hand, found in large quantity in ADE containing a high concentration of calcium and phosphorus, may be responsible for the delivery of those elements into the soil (Neves et al. 2003: 41). The high content of phosphorus shows a high proportion of fish in the diet of indigenous Amazonian communities.

Each of these elements must have been involved in the formation of ADE. Primary concern is to determine which of them was a critical factor. 
Scholars agree that domestic wastes generated by human settlement, remnants of food residues, wastes from the process of preparing food, feces, urine, remains of wooden structures, pottery shards, stone tools, shells, ash and charcoal were key components in ADE production.

Amazonian Dark Earths contain over sixty times more charcoal than the surrounding soils. If the char played the key role in the formation of ADE among communities "producing" ADE a special type of burning charcoal and its distribution had to develop. Amazonian indigenous communities apparently controlled the firing process resulting in charcoal production. It their context, these practices were an important element in the production of terra preta and terra mulata.

Traditionally the slash and burn economy, involving the clearing of small forest patches to gain new fields for cultivation, was regarded as a main carbon source (Jolly et al. 1987: 404). Trees has been cut down, dried, and burned for fertilization of the soil and then selected crops were planted. When nutrients were exhausted the field was left and the crop moved to a new location. Fallow period of oxisols and ferralsols usually took 8-10 years and for terra preta about 6 months (Glaser et al. 2004: 12). The forest returns in the following sequence: first weeds, then fast-growing tropical trees and after several years more mature cover overgrow. In this sense, a slash-and-burn economy is a tropical variety of shifting cultivation (Jolly et al. 1987: 404, Eden 1993: 152), a form of agriculture based on crop cultivation until all the nutrients in the soil are used and a significant portion of mineralized organic matter and the acidity rises to the level that prevents the productive economy (Jolly et al. 1987: 403). Consequently, the field is abandoned and can only be return to production after the recovery of nutrients. According to some researchers this specific economy is the only form of agronomic which can be used in the Amazon as a response to ecological limitations (Meggers 1971: 19-23). Flipping from field to field, Indians could have lived in the forest ecosystem without destroying it, in a subtle and harmonious balance with the environment (Mann 2007: 374). Unfortunately, a slash-and-burn economy has one major drawback, it does not yield enough to maintain a complex and large communities (Mann 2007: 376).
Now, when archaeological studies have provided new evidence for the existence of a complex, agricultural society in the Amazonian past, the theories of economy based on agriculture, the theories of high importance slash-and-burn economy and its contribution to the process of ADE formation were sentenced into oblivion. The ineffectiveness of such management and insufficient amounts of carbon introduced into the soil as a result of high temperature firing is often highlighted (Sombroek et al. 2003: 132). Charred remains of the incomplete decomposition of organic matter, black pyrogenic carbon (PYC) and charcoal are responsible for maintaining a high level of organic matter in terra preta. PYC is produced mainly as a solid carbonaceous residue, including macroscopic distinguishable parts of charcoal and carbon black. PYC found in anthropogenic soils not only acts as a carbon storage, but also is a key factor for the sustained constant fertility of these soils (Glaser et al. 2004: 13).

A very important issue in the process of $\mathrm{ADE}$ is the matter of waste deposal within the site (Erickson 2003: 466). Amazonian indigenous communities are known in historical and ethnographic literature as "clean". The traditional village is usually described as a well-kept and neat. In Amazonia, every community carefully sweeps all waste out of the house and its surroundings and the central square. All impurities are swept outside the house or hamlet to a specially prepared place (Ka'apor Indians and Kuikuru; Heckenberger 2009) or thrown into rivers or streams (Erickson 2003: 465). The clear area has a great symbolic importance as a domesticated cultural space, in contrast to the wild forest areas located in the vicinity of the deposits; a clean village is a pride for the local community. The tidiness has also a more practical use, it protects feet from puncture, from snake bites and disease-causing pathogens from decaying organic debris.

A similar division into deposits zones and more or less "pure" areas could function in the past. Differences in the presence of organic substances within the village could be an evidence. Early Amazonian communities threw all their waste and uncleanness in a direct vicinity of a residential zone. Such "dumps", due to the high organic matter content, are suitable for cultivation but there is no evidence that they were actually used in this way. The only exception may be "kitchen gardens". WinklerPrins (WinklerPrins 2009:205, 206) found that the 
dominant form of manipulation of soil in today's gardens in the lower Amazon is the creation of the terra quiemada ("burnt earth"). Every day wastes and debris are swept and accumulated in one particular place and then, once a week are burnt and ash and unburned remnants of leaves and twigs are mixed with the surrounding sandy soils. Then the mixture is spread around the garden, scattering around trees and shrubs (Glaser et al. 2004: 14). Sweep debris burned in contemporary home gardens will darken the earth and can be the beginning of the formation of a new type of ADE.

\section{AMAZONIAN DARK EARTHS - Terra mulata}

Less known is the second type of Amazonian Dark Earths, lighter terra mulata. "Brown earths" cover the vast areas surrounding the terras pretas (Sombroek 1966, Kern et al. 2003: 71, Myers et al. 2003: 18, Woods et al. 2009: 1). These dark and organic-rich soils do not contain high quantities of ceramic and stone artifacts, likewise, the amount of organic substances correspondingly to them is lower than terra preta (Erickson 2003: 460). Sombroek (1966) believed that they are simply remnants of pre-Columbian cultivated areas. While in the case of terra preta a large amount of charcoal comes from domestic fires, as in the case of the latter, it is the result of low temperature burning of fresh plan materials. Terra mulata is therefore a remnant of the ancient pre-Columbian fields surrounding Indian villages (Myers et al. 2003: 23, Sombroek et al. 2003, Schmidt 2009: 166).

\section{End production of ADE}

Intensification of agriculture, which was a proof of the creation of ADE, is both the cause and the result of the concentration of settlements in Amazonia. When the pressure of the population decreased, improvements of intensive production techniques likewise ceased. Such relaxation began together with the arrival of Europeans and Africans and the associated diseases for which the Indians had no immunity. In the period between 1524 and 1650 European "dominion" in Amazon was established. French, Danish, English, Spanish, and Portuguese fought for supremacy over those areas. To escape from the "white man" Indian masses hid in the forest spreading the deadly diseases. Along with the great societies of Amazonia, the era of ADE ended (Myers et al. 2003: 21, Neves et al. 2003: 38). The memory of the large Indian settlements and their highly productive economies quickly disappeared.

\section{ADE IMPORTANCE IN THE CONTEXT OF ARCHAEOLOGICAL RESEARCH}

Amazonian Dark Earths play a key role in studies of the past, present and future of the Amazon. The size and shape of Amazonian anthropogenic soil sites can be comparable to the historical traces of the indigenous settlement of Amazonia (Myers et al. 2003: 19).

The typical archaeological site in the Amazonia is combined by a unique combination of black earth, pottery shards and the presence of characteristic plant species that William Balée calls "cultural forest" (Schaan et al. 2009: 127). The intensive use of river resources, manioc and maize cultivation (Roosevelt 1980, 1991) enabled the development of a sedentary lifestyle (Lathrap 1970).

On a large scale ADE occurred between 450 BC and $950 \mathrm{AD}$ (Petersen et al. 2001: 100, Erickson 2003: 484, Neves et al. 2003). In most cases, the earliest dates come from the Middle and Lower Amazon River region (Lathrap 1970, Roosevelt 1991, Petersen et al. 2001, Erickson 2003: 484, Myers et al. 2003, Neves et al. 2003). Today, most researchers believe these changes to be associated with increasing population pressure on the environment and increased social interaction (Lathrap 1970, Oliver 2001, Petersen et al. 2001).

There is still one major and fundamental question: whether the creation of ADE involving hundreds of hectares, was the result of a more or less permanent large settlements or rather the result of seasonal relocations of small villages (Neves et al. 2003: 43)? One of the most important hypotheses assumes prehistoric urbanism with large proto-cities and central squares, oval midden mounds and residential areas (Heckenberger et al. 1999). Research conducted by Heckenberger in the Xingu drainage in Brazil has proven the existence of the central plazas surrounded by a vast area of terras pretas. In this case, the occurrence of ADE is confirmed by the chroniclers' relations and provides direct evidence for the large population density in Amazonia at the time of the Contact Era. 
Some researchers agree that the shape of ADE is perhaps related to the settlement pattern and reflects the social organization of the society. Such attempts to correlate $\mathrm{ADE}$ shape with different types of settlement could bring in the future valuable information about Amazonian pre-Columbian settlements.

\section{CONCLUSIONS}

Amazonian Dark Earths provide unprecedented information about the former settlement and economy of pre-Columbian societies of the Amazon. In terms of their properties ADE are an important nutrient storage, enabling the development of agricultural production in this hostile area. Creating fertile soil, the former farmers could effectively raise the standard of living (Woods et al. 2004: 8). By creating models based on experiments, archaeological and ethnographic research, each takes an important lesson about the origins and formation of $\mathrm{ADE}$. The formation process of $\mathrm{ADE}$ as a deliberate effort of pre-Columbian societies was one of the many steps taken to improve the quality of harvest (Thayne et al. 2009: 279) and Amazonian terra pre$t a$ is not a unique thing. Rather, it is part of a global process of accumulation of sediments within human settlements (Woods 1995: 163). Thus, terra preta or terra mulata can be direct evidence for the intensive cultivation of terra firme, crop fields, orchards, backyard gardens and forest modifications over hundreds or even thousands of years (Denevan 1996: 669-670, Rebellato et al. 2009: 21).

Historical ecologists show that Amazonia is largely an anthropogenic environment, transformed beginning at least 10000 years ago, when the first groups of people arrived to the area and brought the most important tool with them - fire. ADE is only one of these modifications.

Long-term, permanent settlement in the Amazonia would be a key ingredient of terra pre$t a$ formation (Erickson 2003: 483). Based on the results archaeological research, historical and ethnographic observations and contemporary analogies we can assume that the issue of deposit or disposal of debris played a major role in that process. Disposal of waste is in fact also a part of the cultural and intentional processes undertaken by the former and current Amerindian communities. "[...] The Amazonian communities - to quote
Erickson - knew exactly what they were doing when it came to settlement, agriculture and other activities that required the transformation of the environment for a long and a short period of time" (Erickson 2003: 483). Terra preta began to form in the sedentary conditions, which in turn are the result of cultural changes and decisions. And these decisions are deliberate and conscious (Erickson 2003: 484). Interesting threads in this discussion introduces the historical ecology, whose primary objective is to claim that indigenous communities were not adapted to the Amazonian environment, but rather adapted the environment by ordinary human creativity, technology and cultural institutions, created the world they wanted. In the agricultural regression model (model assumes that today's farmers live and use the resources of the environment created by their ancestors, not by adapting to it, but rather by exploiting) created by William Balée (Erickson 2003: 456) assumes that today's environment has been created by the effort of hundreds of generations; and Amazonian societies were able to alter soil nutrient levels, improve access to nutrients, change hydrology and vegetation and in the end create new, productive soils. The term "create" includes the scale and significance of what Indian communities have done to improve the environment in which they existed, the work to move the context of organic residues from residential to agricultural fields, cutting and removal of trees and the systematic burning of forest and savannah. Many Amazonian Dark Earths are therefore the result of deliberate human action, but not all of them. We can agree that terra preta, as a result of long lasting settlements and hundreds of years of creation, is not an intentional product. Different is the case of terra mulata - intensive agronomic processes leading to its formation, associated with land improvement, made it the result of deliberate actions.

\section{REFERENCES}

Barreto C. \& Machado J., 2001. Exploring the Amazon, Explaining the Unknown: Views from the Past. [in:] McEwan C., Barreto C. \& Neves E.G. (eds), Unknown Amazon. Culture in Nature in Ancient Brazil, The British Museum Press, London, 232-251.

Denevan W.M., 1996. A Bluff Model of Riverine Settlement in Prehistoric Amazonia. Annals of the Association of American Geographers, 86, 4, 654-681. 
Denevan W. M., 2001. Cultivated Landscapes of Native Amazonia and the Andes. Oxford University Press, Oxford.

Eden M.J., 1993. Swidden Cultivation in Forest and Savanna in Lowland Southwest Papua New Guinea. Human Ecology, 21, 2, 145-166.

Eden M.J., Bray W., Herrera L. \& McEwan C., 1984. Archaeology Terra Preta Soils and Their Archaeological Context in the Caqueta Basin of Southeast Colombia. American Antiquity, 49, 1, 125-140.

Erickson C.L., 2003. Historical Ecology and Future Explorations. [in:] Lehmann J., Kern D.C., Glaser B. \& Woods W.I. (eds), Amazonian Dark Earths: Origin, Properties, Management, Kluwer Academic Publisher, The Netherlands: $455-500$.

Fraser J., Cardso T., Junqueira A., Falcão N.P.S. \& Clement C.R., 2009. Historical Ecology and Dark Earths in Whitewater and Blackwater Landscapes: comparing the middle Madeira and Lower Negro Rivers. [in:] Woods W.I., Teixeira W.G., Lehmann J., Steiner C., WinklerPrins A., Rebellato L. (eds), Amazonian Dark Earths: Wim Sombroek's Vision, Springer, Berlin, 229-264.

Glaser B., Zech W. \& Woods W.I., 2004. History, Current Knowledge and Future Perspectives of Geoecological Research Concerning the Origin of Amazonian Anthropogenic Dark Earths (Terra Preta). [in:] Glaser B. \& Woods W.I. (eds), Amazonian Dark Earths: Explorations in Space and Time, Springer, Berlin - Heidelberg, $10-17$.

Hecht S.B., 2003. Indigenous Soil Management and the Creation of Amazonian Dark Earths: Implications of Kayapó Practices. [in:] Lehmann J., Kern D.C., Glaser B. \& Woods W.I. (eds), Amazonian Dark Earths: Origin, Properties, Management, Kluwer Academic Publisher, The Netherlands, 355-372.

Heckenberger M.J., 2009. Zaginione miasta Amazonii. Świat Nauki, 11, 44-52.

Heckenberger M.J., Petersen J.B. \& Neves E.G., 1999. Village size and permanence in Amazonia: Two archaeological examples from Brazil. Latin American Antiquity, 10, 4, 353-376.

Jolly C.J. \& Plog F., 1987, The Emergence of Food Production. [in:] Ember C.R., Ember M.R., Peregrine P.N. \& Hoppa R.D., Physical anthropology and archaeology, $4^{\text {th }}$ ed., New York, 368-446.

Kämpf N., Woods W.I., Sombroek W., Kern D.C. \& Cunha T.J.F., 2003. Classification of Amazonian Dark Earths and other Ancient Anthropic Soils. [in:] Lehmann J., Kern D.C., Glaser B. \& Woods W.I. (eds), Amazonian Dark Earths: Origin, Properties, Management, Kluwer Academic Publisher, The Netherlands, 77-104.

Kern D.C., D’Aquino G., Rodrigues T.E., Frazăo F.J.L., Sombroek W., Myers T.P. \& Neves E.G., 2003. Distribution of Amazonian Dark Earths in the Brazilian Amazon Dark Earths in the Brazilian Amazon. [in:] Lehmann J., Kern D.C., Glaser B. \& Woods W.I. (eds), Amazonian Dark Earths: Origin, Properties, Management, Kluwer Academic Publisher, The Netherlands, 51-76.

Kern D.C., Lima da Costa M., Lima F. \& Francisco Juv., 2004. Evolution of the Scientific Knowledge Regarding Archaeological Black Earths of Amazonia. [in:] Glaser B.
\& Woods W.I. (eds), Amazonian Dark Earths: Explorations in Space and Time, Springer, Berlin - Heidelberg, 19-28.

Lathrap D.W., 1970. The Upper Amazon. Praeger Publishers, New York.

Lehmann J., Kern D.C., German L., McCann J., Martins G.C. \& Moreira A., 2003. Soil Fertility and Production Potential. [in:] Lehmann J., Kern D.C., Glaser B. \& Woods W.I. (eds), Amazonian Dark Earths: Origin, Properties, Management, Kluwer Academic Publisher, The Netherlands, 105-124.

Mann Ch.C., 2007. 1491: Ameryka przed Kolumbem. Dom Wydawniczy Rebis, Poznań.

Marris E., 2006. Black is the new green. Nature, 442, 624-626.

Meggers B.J., 1954. Environmental Limitation on the Development of Culture. American Anthropologist, New Series, 56, 5, 1, 801-824.

Meggers B.J., 1971. Amazonia: Man and Culture in a Counterfeit Paradise. Aldine - Atherton, Chicago - New York.

Miller R.P. \& Nair P.K.R., 2003. Archaeobotanical Methods for the Study of Amazonian Dark Earths. [in:] Lehmann J., Kern D.C., Glaser B. \& Woods W.I. (eds), Amazonian Dark Earths: Origin, Properties, Management, Kluwer Academic Publisher, The Netherlands, 205-226.

Miller R.P. \& Nair P.K.R., 2006. Indigenous agroforestry systems in Amazonia: from prehistory to today. Agroforestry Systems, 66, 151-164.

Myers T.P., Denevan W.M., WinklerPrins A. \& Porro A., 2003, Historical Perspectives on Amazonian Dark Earths. [in:] Lehmann J., Kern D.C., Glaser B. \& Woods W.I. (eds), Amazonian Dark Earths: Origin, Properties, Management, Kluwer Academic Publisher, The Netherlands, 16-29.

Neves E.G., Petersen J.B., Bartone R.N. \& da Silva C.A., 2003. Historical and Socio-cultural Origins of Amazonian Dark Earths. [in:] Lehmann J., Kern D.C., Glaser B. \& Woods W.I. (eds), Amazonian Dark Earths: Origin, Properties, Management, Kluwer Academic Publisher, The Netherlands, 30-50.

Oliver J.R., 2001. The Archaeology of Forest Foraging and Agricultural Production in Amazonia. [in:] McEwan C., Barreto C. \& Neves E.G. (eds), Unknown Amazon. Culture in Nature in Ancient Brazil, The British Museum Press, London, 50-85.

Petersen J.B., Neves E.G. \& Heckenberger M.J., 2001. Gift from the Past: Terra Preta and the Prehistoric Amerindian Occupation in Amazonia. [in:] McEwan C., Barreto C. \& Neves E.G. (eds), Unknown Amazon. Culture in Nature in Ancient Brazil, The British Museum Press, London, 86-107.

Rebellato L., Woods W.I. \& Neves E. G., 2009. Pre-Columbian Settlement Dynamics in the Central Amazon. [in:] Woods W.I., Teixeira W.G., Lehmann J., Steiner C., WinklerPrins A. \& Rebellato L. (eds), Amazonian Dark Earths: Wim Sombroek's Vision, Springer, Berlin, 15-32.

Roosevelt A.C., 1980. Parmana. Prehistoric Maize and Manioc Subsistence along the Amazon and Orinoco. Academic Press, New York. 
Roosevelt A.C., 1991. Moundbuilders of the Amazon. Geophysical Archaeology on Marajó Island, Brazil. Academic Press, New York.

Schaan D.P., Kern D.C. \& Frazão F.J.L., 2009. An Assessment of the Cultural Practices Behind the Formation (or Not) of Amazonian Dark Earths in Marajó Island Archaeological Site. [in:] Woods W.I., Teixeira W.G., Lehmann J., Steiner C., WinklerPrins A. \& Rebellato L. (eds), Amazonian Dark Earths: Wim Sombroek's Vision, Springer, Berlin, 127-142.

Schmidt M.J. \& Heckenberger M.J., 2009. Amerindian Anthrosols: Amazonian Dark Earth Formation in the Upper Xingu. [in:] Woods W.I., Teixeira W.G., Lehmann J., Steiner C., WinklerPrins A. \& Rebellato L. (eds), Amazonian Dark Earths: Wim Sombroek's Vision, Springer, Berlin, 163-192.

Sombroek W., 1966. Amazon Soils. A Reconnaissance of the Soils of the Brazilian Amazon Region. Centre for Agricultural Publications and Documentations, Wageningen.

Sombroek W., Kern D., Rodrigues T., da Silva C.M., Cunha J.T., Woods W.I. \& Glaser B., 2002. Terra preta and terra mulata: pre-Columbian Amazon kitchen middens and agricultural fields, their sustainability and their replication. $17^{\text {th }}$ World Congress of Soil Science, Bangkok, Thailand.

Sombroek W., Ruivo M.L., Fearnside Ph.M., Glaser B. \& Lehmann J., 2003. Amazonian Dark Earths as Carbon Stores and Sinks. [in:] Lehmann J., Kern D.C., Glaser B. \& Woods W.I. (eds), Amazonian Dark Earths: Origin,
Properties, Management, Kluwer Academic Publisher, The Netherlands, 125-140.

Thayn J., Price K., Woods W.I., 2009. Locating Amazonian Dark Earths (ADE) Using Satellite Remote Sensing - A Possible Approach. [in:] Woods W.I., Teixeira W.G., Lehmann J., Steiner C., WinklerPrins A. \& Rebellato L. (eds), Amazonian Dark Earths: Wim Sombroek's Vision, Springer, Berlin, 279-298.

WinklerPrins A.M., 2009. Sweep and Char and the Creation of Amazonian Dark Earths in Homegardens. [in:] Woods W.I., Teixeira W.G., Lehmann J., Steiner C., WinklerPrins A. \& Rebellato L. (eds), Amazonian Dark Earths: Wim Sombroek's Vision, Springer, Berlin, 205-212.

Woods W.I., 1995. Comments on the Black Earths of Amazonia. Papers and Proceedings of the Applied Geography Conferences, 18, Applied Geography Conferences, 159-165.

Woods W.I., 2003. Development of Anthrosol Research. [in:] Lehmann J., Kern D.C., Glaser B. \& Woods W.I. (eds), Amazonian Dark Earths: Origin, Properties, Management, Kluwer Academic Publisher, The Netherlands, 3-15.

Woods W.I. \& Denevan W.M., 2009, Amazonian Dark Earths: The First Century of Reports. [in:] Woods W.I., Teixeira W.G., Lehmann J., Steiner C., WinklerPrins A. \& Rebellato L. (eds), Amazonian Dark Earths: Wim Sombroek's Vision, Springer, Berlin, 1-14.

Wüst I. \& Barreto C., 1999. The Ring Villages of Central Brazil: A Challenge for Amazonian Archaeology. Latin American Antiquity, 10, 1, 3-23. 